Historic, Archive Document

Do not assume content reflects current scientific knowledge, policies, or practices. 



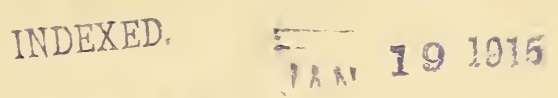

6. 6 (1)

\section{CATALOG AND PRICE LIST}

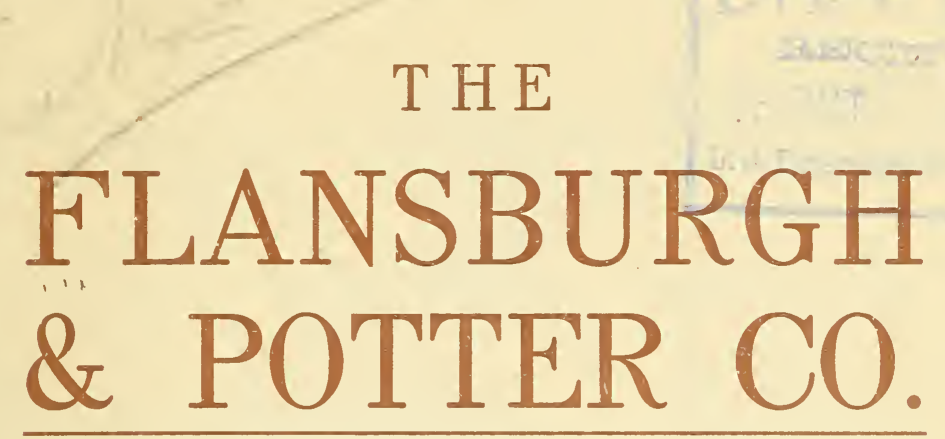

SPRING 1915

Strawberry Plants and Other Small Fruits 䪦

GROWN AND FOR SALE BY

The FLANSBURGH \& POTTER CO. LESLIE, MICHIGAN 


\section{St. Regis Everbearing}

Berries From June Until October

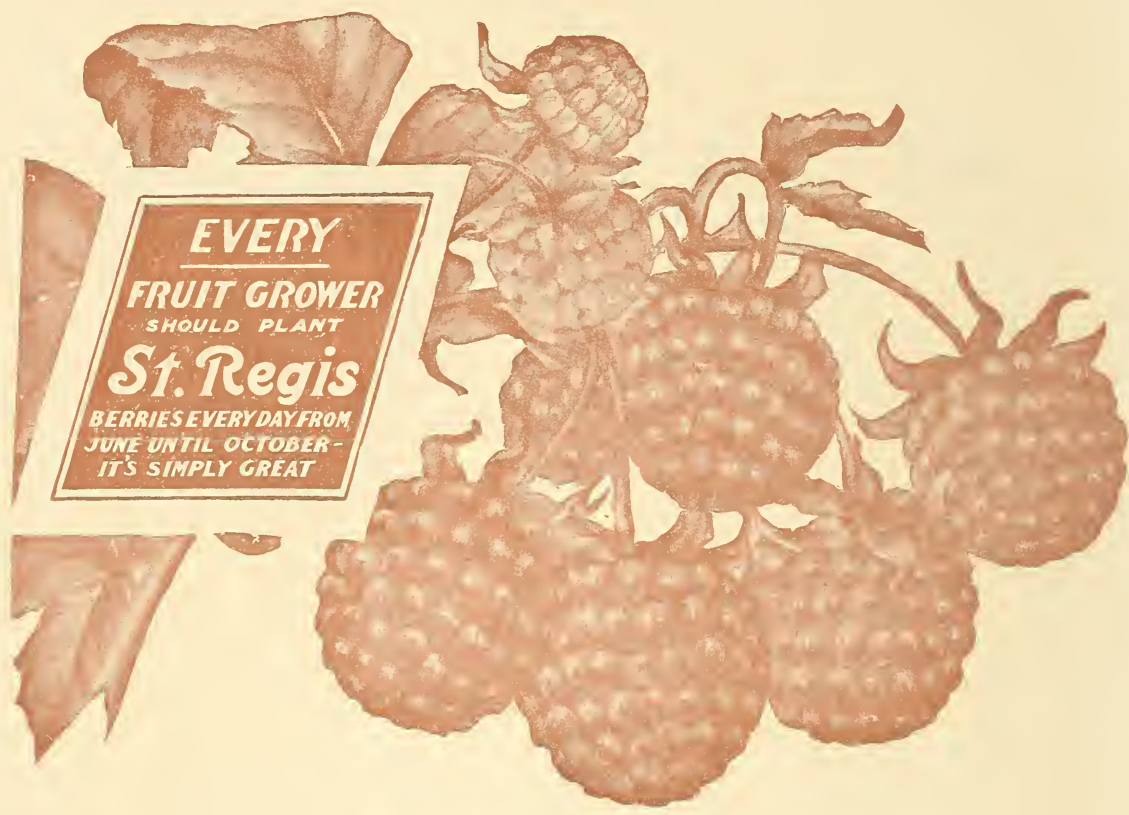

\section{St. Regis Everbearing Red Raspberry}

Raspberries all summer. That's what you will get when you plant St. Regis. This is the first Fall Bearing Raspberry we have heard of. The St. Regis is pure American blood, and of ironclad hardihood, the canes enduring the most severe winter uninjured. After testing this beautiful new variety of Red Raspberry we find it about as represented. Plants set last spring bore some nice fruit this fall. The canes grew large and thrifty which leads us to believe it will be a profitable berry to grow. Try a few.

Price-Each, 5c; dozen, 50c; 100, $\$ 2.50 ; 1,000, \$ 20.00$. Postage 5c per Dozen Extra If Sent By Mail. 


\section{A Visit With Our Customers}

There is a Reason why we should take this way of thanking our customers for their liberal patronage of the past. We cannot shake your right hand as we would like to but we know you are our friends. This business was started over 20 years ago and has had a healthy growth ever since. We have reason to be thankful because you have not only given us your orders, but you have advised your neighbors to send for plants. We have every reason to believe you have been pleased with our plants as we receive so many friendly letters stating, "Plants arrived in fine condition and every one growing." They certainly please us and we want you to know it. We have tried to be careful in our description of varieties, and to thoroughly test them before offering to the trade, but sometimes we wonder if our efforts are appreciated. We are disgusted sometimes to see some small dealer make a big noise about some variety that he knows nothing about. Perhaps we have been too slow in offering all the new things but we have our business at heart and cannot spring them like some dealers we know. We have been slow in offering the Everbearing or the Fall bearing varieties. We have had nearly every one of them in our experimental plot for some time watching them to see if they were worthy of a place in our catalog.

Some say Productive is the best, others say Superb, while others say Americus. We have thoroughly tested all of them and find Progressive the best for this section and honestly believe the best for any section. It has a perfect blossom, makes plenty of plants and produces a good crop of fruit in the fall. Some claim Superb is the best in their section. It is a good variety, but with us it does not make plants enough for a good fruiting row. Americus produces large fancy fruit of extra fine flavor and makes a fairly good plant row. We believe that the Progressive is to the Fall bearing what Dunlap is to the June varieties. You will not be disappointed if you want short cake in September and October, if you plant some of the everbearing.

We have never urged our friends to set largely of the untried "Novelties," but rather to test the new varieties in a small way at first, from our experience. The new Fall Bearing will not be a disappointment to you. We have placed our price within reach of all and hope every one of our customers will try a few plants. 
Our Shipping Season begins with the Southern orders, as soon as frost is out of the ground in spring, often in March. The sooner plants are set, before they get too large a growth, the better. We aim to set out plants in early April. If ordered late in the season, it is always best to name a second or third choice in case a variety is sold out, or leave it with us, stating soil conditions and other particulars. We will do our best to please you, but order early and have plants come early, if you can.

TERMS, Cash with Order; but orders will be booked if one-fourth value is enclosed, the remainder to be sent before shipment. C. O. D. orders require one-fourth value with the order. Send remittance at our risk by postoffice order, express money order, bank draft or registered letter. Stamps taken for parts of a dollar.

Claims, if any, must be made upon receipt of goods, so that mistakes, should any have been made, may be promptly corrected. We take great pains to avoid mistakes, but should any error have been made, please notify us 'of the fact at once.

Canadian Shipments accompanied with invoice, owing to the duty, with charges guaranteed to avoid delay. Please do not send Canadian stamps.

For Our Responsibility address with a stamp the People's Bank, Leslie, Mich., postmaster, express agent, or any official, professional or business man of the same place.

We Grow Our Plants in a New Place Each Season, rotating with clover and other crops on good soil that is still new and capable of producing wellbalanced, best grade plants. The kind we advertise.

We Maintain Our Grade by a careful selection of stock plants, and right methods of propagation from year to year, that tend with such a soil to produce stock of the greatest health and vigor, striving for the ideal fruiting row and perfect fruit from any plants that may be left unsold.

Our Plants Are Fresh Dug as wanted, nicely trimmed ready for planting, carefully re-sorted and tied in bunches of 25; roots washed in cold water if necessary to make them clean, and packed with live moss in new handle baskets lined with oil paper, or in light ventilated crates, in such a manner that we guarantee safe arrival in good condition by express or mail, to all parts of the U. S. and Canada. Plants by freight at buyer's risk.

True to Name. We take great pains to have stock true to name and hold ourselves ready upon proper proof to refund money or replace any that prove untrue; but it is mutually agreed that we shall not be liable for a greater sum than the amount paid for such stock.

Our Prices average lower than can be found elsewhere, when quality of stock and guarantee conditions are considered. Our references for responsibility are ample. You take no risk whatever. See elsewhere a certificate of health from State Inspector of Nurseries, L. R. Taft. Read our unsolicited testimonials. We invite investigation at all times.

A Strawberry plant is never in so prime a condition as when fully grown, matured and dormant. Our friends in the south have recognized that our northern grown plants are safer to set, because of their more dormant condition on arrival, while commercial growers in the north and west would not think of setting southern stock of a more advanced growth. We also hold that, while the strawberry will grow and thrive nearly everywhere, the north is its natural home, where it fits the conditions more naturally for a higher development. 


\section{SUMMER AND FALL PLANTS}

The best time to set Strawberry plants is in the spring and the earlier the better, but they may be set successfully at any time that the young plants are big enough, if there is plenty of rain, or proper care is given.

We are always anxious to accommodate those who wish to test new varieties a year sooner, or who neglected to order the home garden at the proper season or in case of market gardeners, who have crops coming off their ground which they wish to set to Strawberries as a matter of economy and rotation. To such our printed rate per dozen will apply as soon as any plants are large enough. Before September 15 the rate per 100 will be onehalf more; after September 15 our price will be 75 cents per 100; write for price on larger amounts. Later in the season, the loss of plants not well rooted, which must be thrown away, is not so great, and if several thousand are wanted, write for prices on the list desired.

We do not sell potted plants, regarding them as less satisfactory than good layer stock and much more costly for the express. When more than dozens or hundreds are wanted write for prices on the list desired.

\section{Number of Plants Required to Set an Acre}

Distance Plants

1 by 1 foot, 43,560

2 by 1 foot, 21,780

2 by 2 feet, 10,890

3 by 1 foot, 14,520

3 by 2 feet, 7,260

3 by 3 feet, 4,840

Distance
4 by 1 foot, 10,890
1 by 2 feet, 5,445
4 by 3 feet, 3,630
4 by 4 feet, 2,722
5 by 1 foot, 8712
5 by 2 feet, 4,356
5 by 3 feet, 2,904

Distance Plants

5 by 4 feet, 2,178

5 by 5 feet, 1,741

6 by 1 foot, 7,160

6 by 2 feet, 3,630

6 by 3 feet, 2,420

6 by 4 feet, 1,815
Distance Plants

6 by 5 feet, 1,452

6 by 6 feet, 1,210

7 by 1 foot, 6,122

7 by 2 feet, 3,111

7 by 3 feet, 2,074

7 by 4 feet, 1,555

\section{ALL GREW}

Flansburgh \& Co.,

April 30th, 1914.

\section{Gents:-}

Leslie, Mich.

Plants arrived in good time. They were a little dry, but all started to grow. Have bought plants from you before and know they are all right.

$$
\text { Respectfully, }
$$

D. LUNG, Iowa. 


\section{STRAWBERRY CULTURE}

Here it is not our purpose to try to tell you all there is to know about growing strawberries. Many books would be too few to hold all that might be written. It is our intention only to give you the outlines; tell you the things you must do, if you do nothing else. For all the rest we must refer you to the many most worthy books and magazines which deal with these matters. Every strawberry grower ought to have a good fruit paper. If we can set you straight at the beginning on the things which are the most important of all we will be happy to have done so. First and foremost, though, remember that you must have select, high quality, sturdy plants; these lacking, you are all wrong.

\section{SOIL CONDITIONS}

Generally speaking, any soil that will produce a good crop of corn or potatoes will produce a good crop of strawberries. It must be well drained either naturally or artificially. The well drained soil is lighter and better for it will longest keep the moisture the strawberry plant or any other plant must have. Choose a good length of time. Remember that the strawberry ripens at a time when you may reasonably expect drouth. Provide, therefore, far in advance for this very thing. Take lots of pains. Your strawberry crop is of more value than the ordinary farm crop. It will, therefore, repay more completely any work you put on it. Get the soil in perfect condition, supply it with the necessary plant food.

\section{MANURING THE GROUND}

When the soil is at all deficient in fertility we would advise using wellrotted stable manure. If possible, apply it the year previous to setting out the plants and grow some crop that must be thoroughly cultivated or hoed. This will put the soil into the very best possible condition for the strawberry bed.

We would caution against the use of new stable manure for the reason that it contains so often a great many weed seeds which will cause trouble later.

\section{FITTING THE SOIL}

Having the manure spread, the next step is thorough pulverization of the soil. Plow or spade to an even depth, in shallow soil six inches, in deep soil eight niches is not too much-but break evenly. Crop results depend greatly upon the breaking of the ground; a piece of ground unevenly broken cannot be brought into perfect, ideal condition.

Harrow thoroughly two or three times-do it again if you want to, you can't get it too fine for good results. We generally harrow with the furrows then diagonally each way. We then follow with a heavy roller. If you have no roller at hand a plank drag or "float," as we call it, will serve if heavily weighted. This firming of the ground is very important. It is almost impossible to set plants properly if the soil is not reasonably level and firm at the surface. Easy to do all this work at the beginning and it counts all the time your strawberry bed is there.

\section{"MARKING OUT" FOR PLANTS}

Do it any way that will give you a straight, shallow mark to set by. Don't forget that a straight row means easy cultivation by and by. We use a light sled with three runners, one in the middle and one on each side, giving us rows four feet apart. It makes a very satisfactory implement for the purpose. 


\section{SETTING THE PLANTS}

of course you have been taking good care of them since you got them. If possible set them at once. If packed properly, as all ours are, they will be in first-class condition for setting when you take them out of the moss.

When your ground is thoroughly prepared, smooth as a floor and marked in rows, setting of the plants themselves is a simple operation but an important one. Do it yourself unless you can find someone who can do it better. A little practice makes the work easy and rapid. Take your plants in a basket or some other convenient carrier; moisten the roots. If the roots are very long they should be cut back one or two inches, depending on the size of the plant. The plant should be held by the upper part of the crown, make an opening with a dibble or spade just large enough for the roots, then lower the plant until the crown is even with the surface. Press the soil with your foot firmly to each side of the plant to close the entire opening. Don't leave any airholes to take out all the moisture and dry the roots.

\section{CULTIVATE THE STRAWBERRY BED}

Cultivation should begin soon after the plants are set and repeated at least every eight or ten days. Clean and shallow cultivation is the watchword of successful strawberry culture. You should cultivate as soon after rains as the ground is fit. The soil condition should always determine the time of cultivation. Don't allow a crust to form if possible. Weeds are a blessing in disguise, they compel you to cultivate. Don't forget the hoe.

\section{WHEN TO MULCH}

Mulching the plants is one of the most important features to be considered and we cannot lay, too much emphasis on this point. In northerly latitudes where freezing and thawing begin early to alternate, as well as in those colder sections where freezing weather comes to stay a while, mulch should be applied soon after the first hard freeze in the fall, but in the south where mulching is done to retain moisture and keep the fruit clean, it need not be done until shortly after the buds open.

\section{REMOVING BLOSSOMS}

Strawberry plants that are set out this spring should not be allowed to bear fruit until the following spring. The blossoms should be pinched off, for to let them ripen fruit the first year would weaken the growth of the plants and is liable to kill them. Just as soon as you remove the blossom your plant starts to work building up a root system. This heavy vigorous root system is essential to enable the plant to come to its fullest possibilities of production.

\section{CERTIFICATE OF NURSERY INSPECTION NO. 1505}

THIS IS TO CERTIFY, That I have examined the Nursery Stock and premises of The Flansburgh \& Potter Co., Leslie, Mich., and find them apparently free from dangerous insects and dangerous contagious tree and plant diseases.

This certificate to be void after July 31st, 1915.

$$
\text { L. R. TAFT, }
$$

State Inspector of Nurseries and Orchards

Agricultural College, Mich., Sept., 1914. 


\section{CALL AGAIN, MR. THOMPSON}

Flansburgh \& Potter Co.,

April 30th, 1914.

\section{Gentlemen:-}

The Strawberry Plants arrived yesterday in good condition.

Am well pleased with them. Thank you for prompt shipment.

Yours truly,

$$
\begin{aligned}
& \text { E. O. THOMPSON, } \\
& \text { Geauga Co., Ohio. }
\end{aligned}
$$

\section{ALWAYS PLEASED}

Flansburgh \& Potter Co.,

May 5th, 1914

Leslie, Mich.

Gentlemen:-

I want a few Plants for a small patch for home use. I have ordered Plants of you before and have always been pleased with them.

$$
\begin{gathered}
\text { Yours truly, } \\
\text { MRS. BERT MARSH, } \\
\text { Washington Co., Nebraska. }
\end{gathered}
$$

\section{CANNOT KEEP AWAY}

Flansburgh \& Potter Co.,

April 20th, 1914.

Leslie, Mich.

Gentlemen:-

Enclosed find order for Plants. They are so fine I want some more right away.

Yours truly,

MRS. GEO. L. SHIELDS,

Fulton Co., Ill.

\section{ANOTHER PLEASED CUSTOMER}

Flansburgh \& Potter Co.,

February 2nd, 1914.

Leslie, Mich.

Gentlemen:-

It has been some time since I have bought any Plants, but must have a new start now. Your Plants are the ones that put me on my feet and I thank you for the good ones sent me in the past.

Yours truly,

JOHN ADAMS,

Oakland Co., Mich. 


\section{FALL OR EVERBEARING STRAWBERRIES}

As we said in our letter we have been slow in offering the everbearing because we thought they might be merely a fad, and we did not want our customers to be disappointed. We have had Pan-American and Autumn for some time, but we could not say very much for them as Fall Bearing, but we kept on trying out and experimenting with the different kinds as fast as they were introduced realizing that it was possible and quite probable that in the near future a Fall bearing would be found that would prove satisfactory in a commercial way and not merely a garden novelty. During the past few years a great improvement has been made and many new kinds have been originated. Out of all this comes two or three varieties which we believe will prove satisfactory to all who plant them. They have been tried out over a wide range of territory and on nearly all kinds of soil and so far as we can learn from reports and observation Progressive and Superb stand at the head of the everbearers. We especially want each one of our customers to try a few Plants of the Progressive as it is no uncommon thing to pick 20 to 25 crates of berries in the fall from 1000 Progressives set in the spring of the same year, as this variety bears an abundance of fruit on the newformed plants. No doubt it has been considered that fall bearing Strawberries would not make plants freely and bed up like the Spring fruiting varieties, but this theory has been completely knocked out with such varieties as Progressive, Superb, and Americus. The Progressive makes plants equal to Dunlap and carries a load of fruit while it is doing it. To make a long story short the Fall Bearing Strawberry is no longer an experiment but a decided success, and it is now not only possible but exceedingly practical to have strawberries in your garden from May to November.

\section{THEY COME BACK}

Flansburgh \& Potter Co.,

July 21st, 1914. Leslie, Mich.

\section{Gentlemen:-}

I am writing you inquiring about the price of Strawberry plants. Last Spring I ordered 900 Pedigree plants and only 300 lived. I desire to fill out my patch this fall. When is the best time to set. We purchased plants of you some years ago and they were very satisfactory. 


\section{PROGRESSIVE (Per.)}

The best of the fall bearing to date. This is a vigorous, thrifty grower making a matted row 2 or 3 feet wide. In fact the best plant maker of all the fall bearing kinds. The color of the foliage, manner and habit of growth somewhat resembles the Dunlap. The fruit is medium to large in size of a deep dark glossy red. The quality of the fruit is not ordinary or medium, but is extraordinary, ranking with the very best. Mr. Harlow Rockhill of Iowa is the originator of this wonderful variety and he has a reason to be proud of it. He says "Progressive is a leader in this country." Keep blossoms picked off until about July 25 th if you want a full fall crop.

\section{SUPERB (Per.)}

This variety was originated by Samuel Cooper of New York and is certainly worthy of a place in the Fall bearing list. It makes large, beautiful, vigorous and thrifty plants and about enough for a good fruiting row. The plants resemble Glen Mary for size. The fruit is medium to large and very attractive. This variety does not bear so heavily on the first season runners as Progressive, but mostly from the mother plants so it does well in hills. The fruit is of excellent quality and can be shipped a long distance, in fact, all the fall bearing sorts will stand long distance shipping.

\section{AMERICUS (Per.)}

One of the first fall bearing varieties to be introduced. It does not make plants as freely as some other varieties, but produces large fancy fruit. This is a true fall bearing variety, giving a crop the same year it is planted; that is on the plants set in the Spring. We consider the Progressive, Superb and Americus the cream of the fall bearing.

\section{NOTICE}

All bloom stems on the fall bearing plants must be removed up till July 25th. After this date let the plants bloom, and three weeks later you can pick ripe strawberries and the vines will continue to yield fruit up to November. 


\section{PRETTY LATE BUT THEY GREW}

Flansburgh \& Potter Co.,

July 16th, 1914.

Gentlemen.-

The Strawberry Plants that you sent me received all O. K. They were well packed in moss and stood the hot July sun well. I immediately gave them a home in an abandoned hen park and they did not delay showing me they had plenty vitality and appreciated my choice place fixed for them. Ninety per cent of them are growing which is wonderful for Plants set in July. I want to thank you for your promptness in filling my order. Please send me more Catalogs as I have given mine away.

Yours truly,

R. B. JENNINGS,

Wexford Co., Mich.

\section{THE KIND THAT PLEASE US}

Flansburgh \& Potter Co.,

May 5th, 1914.

Leslie, Mich.

Plants arrived yesterday. Set to-day. They are fine, full count. Your price beat them- people a mile. I will pull for you when the occasion demands it.

$$
\text { Yours truly, }
$$

FRED BEYERS,

Gratiot Co., Mich.

\section{ANOTHER PLEASED CUSTOMER}

Flansburgh \& Potter Co.,

May 7th, 1914.

\section{Gentlemen.-}

Your letter received stating you would send me some plants that are money-makers. I am pleased to have you do this. I shall want plants every spring and I shall give you my orders.

Yours truly,

MISS E. ALICE ROGERS,

Des Moines Co., Iowa.

\section{WE THANK YOU}

Flansburgh \& Potter Co.,

May 6th, 1914.

Gentlemen.-

"Enclosed find check for balance due you. Plants came in fine condition. Thank you.

Yours truly,

E. E. LINDSAY,

Crawford Co., Ill. 


\section{OUR TESTIMONIALS}

Are Genuine, every one of them, and unsolicited. Every one is new and we will gladly furnish the Post Office address of any of them to any one who wishes to write them about our plants.

We have tried hard to please our customers and we believe in this we have been successful. We know they appreciate our efforts, because we get a good many orders stating, "Your firm was recommended to me by my neighbor as a good place to obtain plants."

It is a great satisfaction to know just how our customers feel toward us and we are glad to receive their nice letters.

We want the public to know what our customers think of us and so we publish them.

\section{A LONG RIDE BUT THEY GREW}

Flansburgh \& Potter Co.,

$$
\text { May 8th, } 1914 .
$$

Leslie, Mich.

Gentlemen.-

Received the Strawberry Plants some time ago and they were in very good condition. They are all planted and looking fine. Thanks for the Extras.

Yours truly,

GEO. HALADAY, Tulare Co., Cal.

\section{GOOD SERVICE COUNTS}

Flansburgh \& Potter Co.,

May 9th, 1914. Leslie, Mich.

Gentlemen.-

The plants were received in due time and were very satisfactory. We appreciate the service. Thank you for the bunch of Extras.

Yours truly,

GENNESEE CO. NURSERIES,

Gennessee Co., Mich. 


\section{NEW VARIETIES}

\section{HIGHLAND (Imp.)}

This is a recent introduction of the M. Crawford Co., of Ohio, and came with very strong endorsements from the Ohio Experiment Station, who gave it a four-year test, and states that it was the leader in productiveness.

After fruiting we find it to be very productive. The plants are very large, strong and vigorous. The fruit medium to large, bluntly conical; color bright scarlet; flesh red clear through. The price is very reasonable this year, and you should give it a test.

\section{BLAINE (Per.)}

This berry has not been introduced very long, but it seems to be making its way into favor on its own merit. After fruiting it we find that it is as large and late as Gandy, but more productive.

It produces strong, healthy plants with rank foliage, and makes runners enough for a good fruiting row. The berry is large, firm, and the very best of colors. Worthy of trial.

\section{NORWOOD (Per.)}

One of Farmer's introductions, and is supposed to be a cross between Marshal and Corsican. The plants are unusually large, with broad, tall, light green foliage. It does not make many plants. The fruit is conic and regular in shape; color bright red, firm, and good quality. The size is large to very large. It has not been very productive with us unless given high culture.

\section{GREAT SCOTT (Imp.)}

This is a good addition to the large varieties and a worthy rival of any of them. It was given its name "Great" because of its size, and "Scott" in honor of its originator. Mr. Warren, the introducer, states that it is one of the largest of the large varieties. It does not make a large number of plants, but the plants are large in size. The fruit is very large, light colored, with medium firmness, and very productive. A large, fancy variety.

\section{JIM DUMAS (Per.)}

Early. Louis Hubach, of Arkansas, the introducer, states that it is a free plant maker and has very long roots and strong, healthy foliage. It is exceedingly productive and holds out during a long season. The berries ripen nearly as early as Excelsior and average twice as large. The flesh is red all through and of good flavor. The introducer is very loud in his praise, but from what we have seen, it is worthy of it. 


\section{HERITAGE (Per.)}

Mid-Season. After fruiting this variety another season we can say that it came up to our expectations. The plants grow very large with extremely heavy crowns. The fruit is large and handsome. The berry is quite dark, shiny crimson. It is quite a favorite in some sections.

\section{U. S. KING EDWARD (Per.)}

The Ohio Experiment Station gives a good description of it as follows: Large, conical, very slightly necked, regular, uniform, color bright, fresh crimson when fully matured. Glossy and attractive. Flesh light in color, firm, fine grained, mild, sweet and good flavor. Plants large, vigorous and light green in color, making a beautiful fruitage row. A very promising variety.

\section{MATTHEW CRAWFORD (Per.)}

Originated with Mr. Peck, of Missouri. He describes it as making large, stocky plants, resembling the Brandywine in this respect. The fruit stems are rather short and the blossoms and fruit are well protected from late frosts and scalding sun. The berries are conical in form, no mis-shapen or very small ones. The color is a brilliant red, inclining to dark red when very ripe. The flavor is fine, and it is very firm for so large a berry. Mid-season.

\section{MINNETONKA (Per.)}

A seedling of the Splendid, crossed by either Bederwood or Lovett. A new variety from Minnesota, bearing its first crop in 1905, having withstood the hard winter without covering and without injury; having the firmness and richness in color of the Lovett, the shape of Splendid, and much more productive than either; a splendid plant maker, ripening mid-season to late. The fruit is large, above the average size, and very productive. Our pickers prefer this variety, and our customers desire it above all others. We shall plant no other variety for medium to late fruiting. (Introducers.)

\section{FENDALL (Imp.)}

Medium Early. A seedling of Wm. Belt, from Maryland. This berry is remarkable for its immense plants and long fruiting season. The fruit is very large, firm, red to the core, and very productive. The introducer claims under like conditions it produced twice as many berries as Senator Dunlap and three times as many as Gandy. While it has not produced such crops for us, we think it a promising variety and worthy of trial.

\section{SON'S PROLIFIC}

Cross of Bubach and Aroma and claimed by the introducers to be the best shipper, best color and best plant they ever grew. This is pretty strong talk, but we find after fruiting it that it is a fine berry.. It is certainly a wonder for its productiveness of big, shiny berries. 


\section{HUNDRED DOLLAR (Per.)}

Mid-season. This is rather a new variety that was introduced by $\mathrm{Mr}$. Hathaway, of Ohio. He states that it is his belief that there is not another variety, be it large or small, that will outyield this giant among strawberries. It is a good grower of large, stocky plants. The fruit is large, bright red, and of good quality. It resembles our Uncle Jim in shape.

\section{OSWEGO (Per.)}

Mid-season. This is one of the best of the large varieties. We have a good many customers who think there is none that equal it. We have fruited this variety several times, and it has produced some good crops for us. Mr. Farmer, the introducer of the berry, states that it is supposed to be a seedling of Bubach, fertilized by Sharpless. The fruit stalks are upright and unusually strong, holding almost the entire crop from the ground. The fruit is very large, quite firm, bright red, and ripen all over.

\section{DEW (Per.)}

Mid-season to late. This is one of the largest varieties of strawberries we know of. The plants are stocky, with light green foliage. The fruit dark red all over, irregular in shape, quite firm and solid for so large a berry and of good quality, fairly productive. If you are looking for size, plant the DEW.

\section{NORTH SHORE (Per.)}

This berry comes from Máassachusetts, and was originated by a wellknown grower. It makes a good growth of strong, vigorous plants which will produce a fair crop of fine berries of good quality. Would not advise planting on thin, light soil. Those looking for late sorts would do well to try it. Season late.

\section{GOLDEN GATE (Per.)}

Mid-season. Originated in Massachusetts by the noted grower, Mr. Warren. It is a strong grower of large, stocky plants. It has a strong, perfect blossom, with plenty of pollen, which produces large, fancy fruit. We have fruited this variety several times and like its habits.

\section{UNCLE JOE (Per.)}

Mid-season. This variety makes large, stocky plants, which produce big, handsome berries of high quality. It is claimed to be a new and distinct variety, but we find it is similar in many ways to Uncle Jim.

\section{GOOD LUCK (Per.)}

Late. This berry was orignated in New Jersey, but offered to the trade by Mr. Allen, of Maryland, and he says, as compared with Gandy, it is equally as large, more productive, and a few days earlier. In shape it is conical to broad conical or wedge shape, with uniformly smooth, even surface, never seamed or ridged. Color dark glossy, making it very showy, both on the vines and in the package. It makes plenty of plants for a fruiting row.

\section{HUB (Per.)}

Medium, late. Introduced by Mr. Warren of Massachusetts. He claims it is to be one of the best introduced. Since fruiting, we find it has several good points. It has a strong staminate flower, and produces a very large handsome berry of excellent flavor.

\section{AMANDA (Per.)}

Medium to late. New variety. A great plant maker of larger plants. Fruit large and handsome. Very productive. 


\section{PAUL JONES (Imp.)}

From the introducer's description we were expecting something great. After fruiting it we found it to be better than we had expected. It certainly is productive of large, fancy fruit. We understand it has been tested on all kinds of soil and does well. It grows a large, thrifty plant and makes a good fruiting row. The fruit resembles Haverland in shape, but is a little darker in color. As it is considered a light-weight berry, it should be a good shipper. Fairly firm.

\section{JULY (Imp.)}

Late. This berry is claimed to be a very late one, but with us it ripened about the time the Gandy did. We found that it produces fruit a little above medium in size but very attractive. The plants are all that could be asked for, making a good fruit row. The color is perfect, being a brilliant red and glossy. Not firm enough for long shipping.

\section{EARLY OZARK (Per.)}

Early. The introducer of this berry says it is a cross between Excelsior and Aroma. He further states that it is a perfect bloomer and has very large blossoms that are rich with pollen. It is the largest extreme early variety I have ever tested. The plants grow strong and are healthy. The fruit is firm, excellent flavor and good color, being bright red, about the same as the Aroma. It is said to be very productive, but we have not had it in bearing long enough to judge this point. The fruit is large, good color and firm.

\section{MASCOT (Per.)}

We offered this variety last season, but as we have never fruited it we could not say much personally as to its qualities. It has every indication of being a strong competitor for Gandy. The season is just a little earlier, but has a long fruiting season. It is a good plant maker. The berries are a beautiful glossy red color, fair quality and productive.

\section{VIRGINIA (Per.)}

The fine early variety is a native of Virginia, and is said to be a cross between Hoffman and Sharpless. It is about the same season as Excelsior, but is a great improvement over that variety, being of much better quality. It is a good grower and productive of good size, nearly round, bright red, glossy berries of good quality, and moderately firm. Season early.

\section{PINE APPLE (Per.)}

Mid-season. This berry is a good grower and productive of good size, bright red berries. It is firm and good quality. The introducer claims a Pine Apple flavor, which we have not been able to find.

\section{PEARL (Per.)}

We received our plants from Mr. Hobart, of Indiana, and he says: "It is a very late berry of good size, moderately productive, light in color and a good shipper. He says its strongest point is its being so late. The plants made a good growth with us." This is a good late variety worthy of trial. 


\section{METEOR (Imp.)}

Medium to late. A new variety from the east that we haven't fruited, but are favorably impressed with the vigorous growth of the plants. The fruit is said to be much like Sample but larger, more productive and a better seller. The originator says it is not easily killed by frost. After fruiting we find it is about as represented. Producing large, dark red, fancy berries, It is a strong grower with long bushy roots.

\section{GILL (Per.)}

An early variety, uniform in shape, nearly round and above the average of the early varieties in size. The fruit is light red, but has a pleasing flavor. Makes good fruit row.

\section{MONROE (Per.)}

Originated by Mr. Morgan, of Srottville, N. Y., and is said to be a seedling of the Sample. Mr. Morgan describes it as a very, very smooth, dark red berry with healthy green calyx firmly embedded in the fruit, which is extra firm with high qualities. Much like Wm. Belt in flavor and color, but firmer and more uniform in shape. The blossoms are perfect and they continue to bloom through a long season. The plant is a good one, making plenty of runners. We are quite well pleased with this variety. Better give it a trial.

\section{OREM (Per.)}

Late. Claimed to be later than Gandy. More productive and larger. Plants made a good growth. After fruiting one season, we believe it is going to be a valuable variety on account of its lateness. Fruit is large.

\section{WOOSTER (Imp.)}

Mid-season. Mr. Wooster, in offering this berry to the trade, says:

"The Wooster is a chance seedling found in an old bed of New Yorks that were fruiting the second season. Refore the New Yorks were planted there it was a bed of Sample, fertilized by Clyde on either side. In certain ways the Wooster resembles all three, but is entirely distinct. The foliage is remarkably strong and upright; fruit stems also very long, but weighed to the ground by the immense load of green and ripe fruit of fine form and color, resembling Sample in that respect, but the set of the seed resembles Clyde more; the quality much better than either of these varieties, and more desirable in every way."

\section{ST. LOUIS (Per.)}

While some claim this variety is a second early, we find it extra early and one of the first to ripen. We have been highly pleased with it for some time and can recommend it as Queen of the Earlies. This berry is not firm enough for long shipping, but as it has so many good points every grower should plant some. Mr. Bauer, the introducer, claims to have grown them so large that twelve of them would fill a quart basket. As grown here, it makes a strong, healthy plant, with plenty of runners. Fruit very large for such an early berry. Light, red color, nearly round and good quality.

If You Fancy Berries Try Our Uncle Jim. 


\section{OHIO BOY (Per.)}

We have fruited this new variety and find it to be a promising variety. It is a rank grower and makes many plants. The fruit is large, dark red and good. It is sometimes a little rough in appearance. Medium to late.

\section{BARRYMORE (Per.)}

This berry was originated in the east. During the Massachusetts Horticultural Show in 1908 this variety was awarded a silver medal and three first premiums, which is quite a record for a new berry. We have had this variety in our trial bed for two years and are pleased with it, both in fruit and plant. The berries are rich, dark crimson, with red flesh of good quality. The fruit is good size and firm enough to ship, size large, and ripens at midseason.

\section{BETHEL (Per.)}

Does well in some sections while in some others it does not give satisfaction. It ripens with Dunlap and continues bearing a long time. It makes a fairly good plant row, the plants being large foliage and thick. It is quite productive of large, dark red, firm berries of good quality.

\section{MANHATTAN (Per.)}

This new berry hails from New Jersey and the introducer claims it to be a monster in size. He describes the fruit as large and uniform; texture very firm but not coarse; color red and glossy; the flavor being excellent, comparing favorably with Marshall and Wm. Belt. Plants are very large.

\section{GIBSON (Per.)}

This is not the old variety of that name which originated in eastern New York several years ago, but a distinct variety of local fame. The berry is large and regular in shape, holding its size well to the end of the season. Color rich red. Flavor is neither too sweet nor too sour, but just right for canning. It made a good plant row and is worthy of trial. 


\section{FIRST QUALITY (Per.)}

Fruited here for the first time under favorable circumstances. About same season as Sample. One of the best growers and as prolific as any late variety. The fruit is large, dark red and good.

\section{KELLOGG'S PRIZE (Per.)}

This is a pistillate variety said to ripen later than Sample or Stevens' Late Champion. The introducer says: "It is very high colored with golden seed, the rich color extending to the center. Flavor is delicious and nothing excels it as a shipping berry. The cap is ample and in harmony with the size of the berry, and the foliage is very large." Not fruited here.

\section{WARREN (Per.)}

This variety hails from Massachusetts and was originated by Mr. Warren, the veteran grower of fancy berries. Being introduced by Mr. Allen of Maryland is enough to say that it must be a promising sort. He says it is a good plant maker, produces abundance of large fancy berries that will stand shipping. Not fruited here.

\section{REWASTICO (Per.)}

Originated with Mr. Howard of Maryland and introduced by Mr. Allen of the same state. He said so many nice things regarding this variety that we were induced to try a few plants. The introducer says it is a highly colored, large cardinal red berry, and very productive. It makes plenty of plants for a good fruiting row. Not fruited here.

\section{GLAD THEY PLEASED YOU}

Flansburgh \& Potter Co.,

June 22nd, 1914. Leslie, Mich.

Gentlemen.-

The Plants you sent me this Spring are thriving nicely. They look fine. Please send me two more Catalogs. Think I will need more Plants next Spring.

Yours truly, 
Flansburgh \& Potter Co.,

\section{WELL ROOTED AND FINE}

May 12th, 1914.

Leslie, Mich.

Gentlemen.-

I received the Plants and they were fine, large and well rooted Plants. Thanks for the liberal count.

Yours truly,

A. B. DAILEY,

Steuben Co., Ind.

\section{PLEASED CUSTOMER IN CANADA}

Flansburgh \& Potter Co.,

May 12th, 1914.

Leslie, Mich.

Gentlemen.-

Received both the shipments of Strawberry Plants all right.

Please accept my thanks for nice Plants and the bunch of Red Bird.

Yours truly,

ÁLBERT E. HOLDER,

Thunder Bay Co., Canada.

\section{WE GIVE GOOD COUNT}

Flansburgh \& Potter Co.,

April 27th, 1914.

Leslie, Mich.

Gentlemen.-

I am sending the postage you ask for. I want to thank you for the good count and the little bunch of Springdale you gave me. Yours truly,

ALBERT J. LIVEZEY, Belmont Co., Ohio.

\section{BEST EVER}

Flansburgh \& Potter Co.,

May 10th, 1914. Leslie, Mich.

Gentlemen.-

I received the Plants in fine condition. Can say they are the best we ever received from any Nursery.

Yours truly,

MRS. HENRY DULEY,

Stoddard Co., Mo. 


\title{
OTHER VARIETIES
}

\author{
IN ALPHABETICAL ORDER
}

\begin{abstract}
ABINGTON (Per.)
I have been growing strawberries for market twenty years, but have fruited the Abington, and it is the best all-round market berry that $I$ have ever raised. In productiveness it is away ahead of Bubach $\mathrm{nr}$ Sharpless. The color is bright red; it is firm and of good quality, and has yielded at the rate of 9,720 quarts per acre in matted rows. I claim it is the best yielder and the largest matted row perfect berry that has been introduced to date. (Introducer.)

We have fruited Abington four years and find it is a strong grower. with large, luxuriant foliage. The fruit is large, quite similar in size and shape and color to Sharpless, but more abundant. Mid-season.
\end{abstract}

\section{ARKANSAS BLACK (Per.)}

One special feature of this variety is its stooling habit, making large plants with many crowns and few new plants. The fruit is large, very dark red, nearly black, firm and of good quality. This is a valuable variety for any collection. A decided novelty as well as a good variety. Medium early.

AROMA (Per.)

One of the most popular late market varieties. A good plant and a good bearer of large, handsome fruit; bright red in color; uniform roundish heart shape; firm and of good quality. Somewhat resembles Gandy in appearance. A choice variety and reliable.

\section{AUGUST LUTHER (Per.)}

Standard early market. For several years this has been our first choice for early market among the standards. More desirable than Excelsior with us, as of better quality, larger average size and ripening more berries in the early season. A good grower and reliable. Fruit large, glossy bright red, firm and of good quality. This berry comes early, always making a good crop before berries lower much in price, and is growing more productive every year.

\section{BEDERWOOD (Per.)}

Well-known standard early market variety. A tough, healthy grower. Very successful, especially in the west prairie country. Fruit medium to large size; round, bright red, good quality. A good carrier and very productive. 


\section{BRANDYWINE (Per.)}

Fruit large, dark red, quite firm; good quality; not always at its best in some sections, but a good variety in others; requiring strong loam soil and high culture for best results. Medium late.

\section{BUBACH (Imp.)}

Fruit large, moderately firm; good color and quality; well known standard variety; productive and reliable. Mid-season. We are nearly always sold out of this variety before the season is over.

\section{BUSTER (Imp.)}

Immensely productive. This is a good grower, with tall, green foliage. The fruit is large to very large, globular in form, bright red color; medium firm and good quality. It begins to ripen in mid-season and continues to very late. This is a Canadian variety that is coming to the front rapidly. We hear nothing but good reports of it wherever fruited.

\section{CAMERON'S EARLY (Per.)}

Extra early. This fruit is of good size for so early a berry; medium red in color and of good quality. A vigorous grower, with tall foliage to protect the bloom from late frosts. Productive and reliable.

\section{CARDINAL (Imp.)}

A strong grower, with long runners. Fruit large, roundish, conical, dark glossy red color. Very beautiful (larger and more beautiful than is shown in the colored plate in the Government Year Book). So great is the demand for plants of this new variety that we were practically sold out last year quite early in the season. In 1912 we had quite a bunch to fruit, which made a good crop of extra fancy fruit. Because of the drouth last summer and the failure of many plants to get well rooted in due season, we are liable to be sold out quite early. The fruiting season of the Cardinal is medium late.

\section{CLIMAX (Per.)}

Fruit large, red to the center, firm, handsome and of good quality. A good grower and productive. A very popular market variety in the east, where it is well known and largely planted. It ripens medium early, and bears a long time. Since this variety was offered the demand for the plants has been very heavy.

\section{CLYDE (Per.)}

Very productive. Fruit large, round, bright glossy red. Large, healthy plants. Well-known standard market variety. Mid-season. 


\section{COMMONWEALTH (Per.)}

Very late. James Monroe, the introducer, in his description says the Commonwealth is the outcome of the desire and effort to produce a berry that would lengthen the strawberry season. In it we have a berry that is as large as the largest, as productive as any, as fine flavor, as solid, and as dark a color as any. The plant is a strong grower, but not so rank as some. The fruit is large, firm, dark color and very handsome. Judging from the orders we have received for these plants, our customers are beginning to realize what a valuable variety this is for late fancy fruit. Later than Gandy.

\section{CORSICAN (Per.)}

This is a favorite variety, especially around Rochester, N. Y. The plants are large and good growers. Fruit large, longish heart shape, good quality; stands shipment well. Mid-season. Very similar in plant and fruit to Uncle Jim. A good variety.

\section{CRESCENT (Imp.)}

A tough, healthy vigorous grower. Fruit medium size, bright red, fairly firm, and of fair quality. Very productive. Mid-season.

\section{CRIMSON CLUSTER (Per.)}

The finest late variety ever fruited. It was found near an old bed of Gandy, and is supposed to be a seedling of that variety. The plants are much like Gandy, but better plant-makers. Will do well on light soil, and produce one-third more per acre. The fruit is of the same shape and color, as large and firm, has a large green cap, ripens two days later, and continues longer in bearing. (Introducer).

We have fruited this variety five seasons, and find it very similar to Gandy, as above described. When Gandy is not at its best, try Crimson Cluster.

\section{CHIPMAN (Per.)}

This berry seems to be a favorite in the east, where it was introduced. Mr. Todd, the introducer, has placed it at the head of his list because he thinks it is the best all-round variety he knows of. He says many more good things regarding it, and as we know him to be reliable, we are firmly convinced that it is a valuable variety wherever it succeeds. The plants are strong, upright growers, large and healthy, with bright, glossy green foliage. The fruit is large, moderately firm, and of good quality.

\section{DUNCAN (Per.)}

A Canadian variety that we have fruited four seasons with much satisfaction. The plants are vigorous, healthy growers. The fruit is large, dark red, firm, and of good quality. It ripens early and continues fruiting a long time, bearing heavily. 


\section{DICKEY (Per.)}

This was one of the novelties of 1907 , originated by J. D. Gowins, of Massachusetts, and introduced by C. S. Pratt. We quote Mr. Pratt's description. "It is a better berry than Sample. It is productive, firm and as large. The Dickey will produce as many quarts of fruit as Sample and will sell for three of four cents more per quart in the market. Mr. Pratt introduced Sample." He further says: "I have been growing strawberries for forty years, and have never seen a finer thing in the berry line in my life."

The Dickey with us is a strong grower, healthy and productive. Fruit large and good quality. The first berries to ripen are rough and irregular, but later in the season they are better.

\section{ENHANCE (Per.)}

Fruit large, bright red, firm and of good quality. Tough, healthy, vigorous plants. Productive and reliable. A standard variety and a favorite, especially in the west. Mid-season to late.

ENORMOUS (Imp.)

Fruit large, bright, glossy red; firm and of good quality; a good grower; productive and reliable. Mid-season.

\section{EXCELSIOR (Per.)}

The well-known standard early market variety. Plants vigorous, making many runners. Fruit medium to large size; round, dark red; firm; quite tart. Reliable and productive.

\section{FREMONT WM. (Per.)}

Late. Mr. Hubach, of Arkansas, the introducer, claims it is the best late strawberry. He also states that it is fine in shape and color as Gandy and ripens the same season, but holds out longer. We find it to be an excellent late sort. It is thrifty in plant and foliage and a free plant-maker. The fruit is large and very handsome. The Ohio Experiment Station, after thoroughly testing the variety, claimed it to be larger and more productive than Gandy.

\section{IT SOUNDS GOOD}

Flansburgh \& Potter Co.,

May 20th, 1914. Leslie, Mich.

Gentlemen.-

Potatoes arrived all O. K. Many thanks for your promptness and nice seed. Will call again.

Yours truly,

ROBERT SCOTT, Monroe Co., Mich. 


\section{FAIRFIELD (Per.)}

Early. This variety makes medium size plants, tough and hardy, with long roots. The berry is good size for an early variety, long, very dark in color and of good quality. It is late in blooming for an early berry, which is an advantage in northern localities.

\section{GANDY (Per.)}

Fruit large, firm, high quality and handsome. A good grower and productive. The well-known standard late shipping berry.

\section{GLEN MARY (Imp.)}

Fruit large, dark red, quite firm and good quality. A good grower, productive and reliable. This variety has small stamens, sufficient for itself, but not to fertilize adjoining pistillates, and so we class it as an imperfeet bloom. Mid-season to late.

\section{HELEN GOULD (Imp.)}

Originated by J. R. Peck, of Missouri, but introduced by M. Crawford Co., of Ohio, and his description in part is: "It makes plants of generous size, sends out a moderate number of runners, and is a plentiful yielder. The fruit is large, roundish conical, glossy red and moderately firm. Its fiavor, though not the sweetest, is delicious."

\section{HAVERLAND (Imp.)}

Very productive. Fruit large, rather long; bright light red; firm, good quality. Plants large and vigorous. Well-known standard variety and reliable. Season early to late.

\section{JESSIE (Per.)}

Fruit large, roundish-conical; bright, glossy red; handsome and of good quality. Not very firm. A moderate plant-maker, fairly productive. A good variety, but, like the old Sharpless, the bloom is large and very tender to frost.

\section{KLONDIKE (Per.)}

Fruit large, round, dark glossy red, good, quality. Plants medium size and vigorous. Productive and reliable. Mid-season.

\section{LATEST (Imp.)}

Fruit large to very large; light glossy red; rather long; good quality. Not firm enough to ship far, but a fine variety for the home or nearby fancy market. Very productive and very late. A moderate plant-maker of large, stocky plants. This is a handsome berry and highly prized by many.

\section{LOVETT (Per.)}

Well-known standard market variety. Fruit large, bright red; firm and of good quality. A good grower, productive and reliable. Mid-season. 


\section{MARIE (Imp.)}

Fruit large, round, uniform in size and shape as Gandy, and about the same color; a handsome berry, especially when crated. A good grower and very productive. This is one of the most reliable heavy croppers we have ever grown. A money-maker. We have never had a bad report of it. Season medium to very late.

\section{MARSHALL (Per.)}

A standard of excellence. Fruit large. Very dark red; heart shape; firm and of high quality. A moderate plant-maker of large, stocky plants.

\section{NETTIE (Imp.)}

This is an old variety. Although its color and appearance are unattractive and its quality not very good, it holds its place by reason of its extreme lateness. It is very large and productive, which makes it profitable regardless of its failings. Very late.

\section{PARSON'S BEAUTY (Per.)}

A good, healthy grower and an immense cropper of large, solid, dark red berries of good form and quality. There is probably not a variety among the standards that will outyield it, or a more reliable. A first-class variety, with a long season.

\section{PENNELL (Per.)}

Fruit large, nearly round; dark, rich red color; firm and of the very highest quality. We think more of the Pennell every year. It always bears abundantly, and is one of the varieties to which we direct friends who visit us at fruiting, who want something extra fine. Grow Pennell on strong loam and be surprised with the large size and excellence of this berry. An all-season variety.

\section{GOOD TREATMENT COUNTS}

Flansburgh \& Potter Co.,

April 1st, 1914.

Gentlemen.-

$$
\text { Leslie, Mich. }
$$

I am very sorry you cannot fill my order. I would rather buy Plants of you than any one else as you have always treated me fine and sent fine Plants. If I need any next season you will get my order.

Yours truly,

$$
\begin{aligned}
& \text { CHARLES WYANDT, } \\
& \text { Huron Co., Ohio. }
\end{aligned}
$$




\section{PRIDE MICHIGAN (Per.)}

Mid-season. From Mr. Baldwin, of Bridgman. There seems to be two varieties by this name, but as the Kellogg strain is similar if not identical with New York, which was discarded by us some time ago, we will only offer the Baldwin strain. The berries are large, rather oblong, very bright red, glossy and beautiful. It being very firm makes it an excellent shipping berry. The plant is vigorous and healthy, making a good fruiting row in any kind of a season.

\section{RIDGEWAY (Per.)}

Fruit large, nearly round; bright, glossy red color; moderately firm, and of good quality. A good grower, productive and reliable. Mid-season.

\section{RED BIRD (Per.)}

An early variety from Mississippi; a cross between Murray and Hoffman, both extra early. The plant is vigorous and fruit is good size, firm, bright red, glossy and beautiful. They produced a good crop the past season. Early and mid-season.

\section{SAMPLE (Imp.)}

Standard market variety. Mid-season to late. Fruit large, roundish conical; bright, glossy red; moderately firm and of good quality. A good grower. Productive and reliable.

\section{SENATOR DUNLAP (Per.)}

This variety has given general satisfaction in almost all sections and all kinds of soil, and the demand for plants increases each season. It makes plants of only medium size but tough and hardy, with long roots and a surprising capacity for enduring hardships. It is very productive and usually matures every berry. They are of good size, bright glossy red, and of excellent quality. It is a first-class shipper and retains its brightness long after being picked. It ripens early and continues a long time in fruit. It is grown largely as a commercial berry.

\section{SPLENDID (Per.)}

Fruit large, nearly round, bright red color, firm and of good quality. Well known, vigorous and hardy grower. Productive and reliable. Midseason.

\section{SPRINGDALE BEAUTY (Per.)}

A strong grower and abundant bearer. The fruit is large, firm and of high quality, resembling the Marie in appearance, and the two sorts make a good team. It ripens early and continues fruiting a long time, holding out large to the end of the season. A good variety. 


\section{STEVENS LATE CHAMPION (Per.)}

A comparatively new variety that has become rapidly popular as one of the very best late varieties for market. It is a splendid, healthy grower, with tall, dark green foliage and long runners. The fruit is large and fine, resembling Gandy. Firm and of good quality, outyielding Gandy here last year and selling at the highest prices. It is certainly a good variety.

\section{WARFIELD (Imp.)}

The well-known standard shipping and canning berry. Plants very vigorous and productive. Fruit large, nearly round, dark, glossy red, firm and of good quality. Mid-season.

This and Dunlap make a good, strong team.

\section{WM. BELT (Per.)}

This variety is largely planted in some sections, while in others it is inclined to rust. It is a fancy variety that always brings fancy prices. It is quite productive, berries very large, rouncish conical, color a bright, glossy red, and the flavor good. Mid-season.

\section{3-W (Per.)}

Introduced by Mr. Mason, of Kentucky, and in his description he says: "Plant very large and vigorous, with a wonderful root system. Fruit uniformly large, glossy and red through and through. Fine quality, and very productive, covering a long season from medium to late. It is remarkably firm and has wonderful keeping qualities."

This berry has done exceedingly well for us. Give it a trial.

\section{CHESAPEAKE (Per.)}

This is comparatively a new variety. If it was a better plant-maker it would be the leading late berry, for it has them all beaten for size, productiveness and quality. We have tried it on all kinds of soils, but fail to get a good plant row. We hear similar results from other sections. The berry is large and regular in shape; color light red. Quality much better than Gandy. 


\section{TWELVE HUNDRED DOLLARS PER ACRE}

Flansburgh \& Potter Co.,

March 28th, 1914.

\section{Gentlemen.-}

Enclosed find order for Strawberry Plants and check to cover same. I ordered my first Plants from you twenty years ago. I have set beds in several places in Western Nebraska and in all cases have purchased the plants of you. The plants were in the semi-arid West where they had to be irrigated from windmills. In every case I have had more plants live than I bought. For the past three years my strawberries have averaged fifty boxes from each square rod of land, or 8,000 boxes to the acre. I find a ready market at $15 \mathrm{c}$ per box, which amounts to $\$ 1,200$ per acre.

Yours truly,

M. J. MOTT, Scott Co., Kansas.

\section{PLEASED}

Flansburgh \& Potter Co.,

May 9th, 1914.

Gentlemen:-

Enclosed find order for plants I bought from you last season and they are fine. Thanking you for nice plants, I am,

Yours truly,
ANTON
U. THORHANG,
Dane Co., Wis.

\section{VITALITY COUNTS}

Flansburgh \& Potter Co.,

August 25th, 1914. Leslie, Mich.

Gentlemen:-

I am in receipt of your letter stating that you can furnish Dunlap about Sept. 20th. We have had a severe drouth here, but I have been able to save the plants bought of you this spring and they are looking fine.

Yours truly,

C. M. KNAPP, Phelps Co., Mo. 


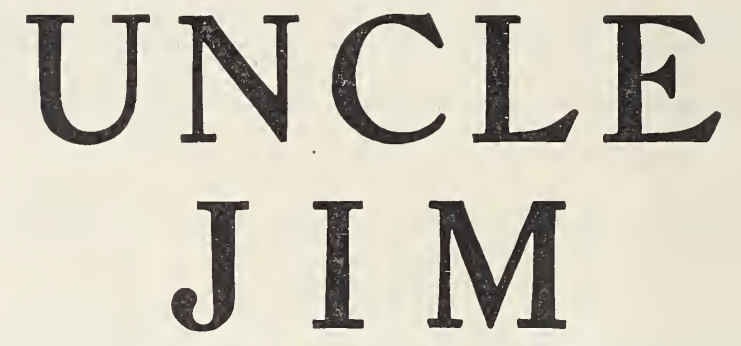

\section{UNCLE JIM (Per.)}

Ever since we introduced this variety we have given the history and a long description of it. Since it is so well known we feel it is useless to write so much. For the benefit of those who receive this catalog for the first time we give the following description: This variety is an excellent grower of large stocky plants. The roots grow down deep in the soil, making it very popular in sections with limited rain fall. The fruit is very large, high colored and of excellent quality. It is famous for its delicate rich sub-acid flavor which makes it possible for the most confirmed dyspeptic to enjoy. We can recommend this variety to those looking for large fancy fruit. 


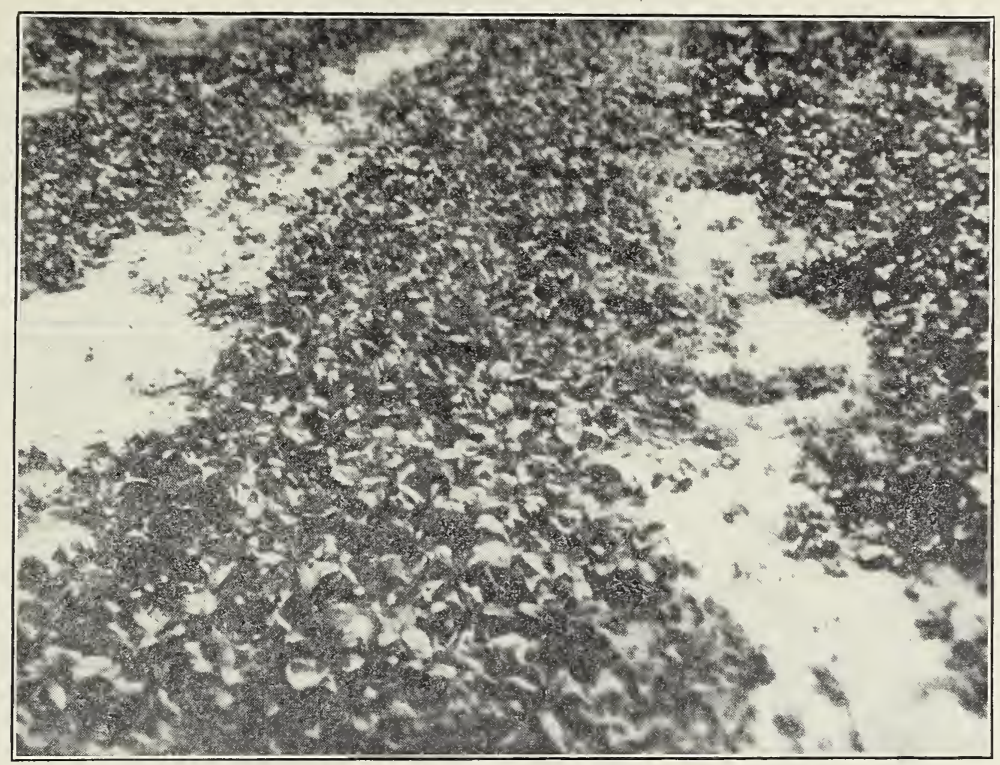

Oct. $11,1914$.

Flansburgh \& Potter Co.,

Leslie, Mich.

\section{Gentlemen:-}

Enclosed find photograph of a part of my strawberry patch. The large row is Uncle Jim. These plants were set April 15th and the photo was taken Sept. 3rd. These plants were bought of your firm and have made a fine growth this summer.

Yours truly,

S. W. FILSON,

Scott Co., Kansas.

\section{A SATISFIED CUSTOMER}

Flansburgh \& Potter Co.,

June 26th, 1914. Leslie, Mich.

Gentlemen:-

The Uncle Jim Strawberry Plants that I received from you are now in bearing and I can truly say that they are a wonderful berry in size, quality and productiveness.

$$
\text { Yours truly, }
$$

R. B. JENNINGS. 


\section{EATON RED RASPBERRY}

In 1905 we introduced this variety and have grown them quite extensively ever since. In some sections it is not liked on account of its dwarf growth. It wants rich sandy loam to do its best. It is not a rampant grower like Cuthbert, but it is inclined to throw out a good many branches which gives it a large fruiting surface. Fruits about same season as Cuthbert, but will outyield it 2 to 1 . It has a much longer season as we usually pick them about 6 weeks. The fruit is large and very handsome. The Eaton makes few suckers compared with most varieties so the price will always be high.

\section{Price of Plants.}

By Express-5c each-40c per dozen-\$2.00 per $100-\$ 17.00$ per 1000 500 at 1000 rate -50 at 100 rate.

Flansburgh \& Potter Co.,

June 2nd, 1914. Gentlemen:-

The Eaton Raspberry vines procured of you a year ago are doing very well in this climate. It is right on the coast. Vines fruit prolifically and surpass the Cuthbert. Am very much pleased with them. They are the best Raspberries raised near here, and would be a profitable crop to raise on a large scale.

Respectfully,

A. W. ROBINSON, Santa Cruz Co., California.

\section{YELLOW DENT CORN}

In recent years a good many of our customers have asked for good seed corn. Last season we offered yellow dent corn and we suppose some may think this is just ordinary corn, but they are certainly mistaken. Our corn is all selected in the field and only the very best offered. It is thoroughly dried and kept in our building which is frost-proof. This corn is a very heavy yielder and you will be pleased with results if you plant it. The ears are of handsome appearance, rich yellow, wedge shaped kernels packed closely on the cob from butt to tip. This corn matures in 80 to 90 days, under average conditions.

Sample ears, 15c-1 lb., 25c. Peck, shelled, 85c. Half bushel, $\$ 1.50$. Bushel, \$3.00-f. o. b. Leslie. 


\section{PRICE LIST-STRAWBERRIES}

The prices by express, not prepaid, 500 at 1000 rate.

\section{$P$ for Perfect; I for Imperfect. READ CAREFULLY}

Customers living within 150 miles can benefit by having their plants sent parcel post, but when being sent farther than this express is as cheap. If sent farther than 150 miles by mail add 25c per 100 for postage. Anywhere within 150 miles plants can be sent for about 10c per 100. Ask your postmaster about the distanee.

\begin{tabular}{|c|c|c|c|c|c|}
\hline Abington $\ldots . . P$ P & $\begin{array}{l}12 \\
15\end{array}$ & $\begin{array}{l}25 \\
20\end{array}$ & $\begin{array}{r}100 \\
60\end{array}$ & $\begin{array}{l}250 \\
110\end{array}$ & $\begin{array}{r}1000 \\
400\end{array}$ \\
\hline Arkansas Black.P & 25 & & & & \\
\hline Aroma ........P & 15 & 20 & 50 & 110 & 400 \\
\hline Aug. Luther ..P & 15 & 20 & 50 & 100 & 325 \\
\hline Armanda $\ldots .$. P & 20 & 35 & & $\ldots$ & $\cdots$ \\
\hline Americus ....P & 30 & 50 & 150 & $\ldots$ & $\cdots$ \\
\hline Barrymore .....P & 20 & 30 & 100 & & \\
\hline Buster ........ I & 15 & 20 & 50 & 110 & 400 \\
\hline Bethel ........P & 20 & 30 & 100 & & \\
\hline Blaine $\ldots . .$. P & 15 & 20 & 50 & 110 & 400 \\
\hline Bubach .......I & 15 & 20 & 50 & 110 & 400 \\
\hline Bederwood .....P & 10 & 20 & 50 & 90 & 300 \\
\hline Brandywine $\ldots \mathrm{P}$ & 15 & 20 & 50 & 110 & 400 \\
\hline Climax ......P & 15 & 20 & 50 & 110 & 400 \\
\hline Cardinal ....... I & 15 & 20 & 50 & 100 & 350 \\
\hline Chesapeake ....P & 15 & 25 & 60 & 135 & 500 \\
\hline Clyde $\ldots . . . . P$ & 15 & 20 & 50 & 110 & 400 \\
\hline Corsican .....P & 15 & 20 & 50 & 110 & 400 \\
\hline Crimson Cluster $\mathrm{P}$ & 15 & 20 & 50 & 110 & 400 \\
\hline Crescent $\quad \ldots$. I & 15 & 20 & 50 & 100 & 325 \\
\hline Chipman $\ldots$. P & 15 & 20 & 60 & & . \\
\hline Commonwealth $\mathrm{P}$ & 15 & 20 & 50 & 110 & 400 \\
\hline Cameron Early.P & 15 & 20 & 50 & 90 & 300 \\
\hline Dickey ......P & 15 & 20 & 60 & . & $\cdots$ \\
\hline Dew .......P & 25 & 40 & 125 & & \\
\hline Excelsior & 15 & 20 & 50 & 90 & 300 \\
\hline Early Ozark ...P & 15 & 20 & 50 & 110 & 400 \\
\hline Enormous $\ldots .$. I & 15 & 20 & 50 & 110 & 400 \\
\hline Enhance $\ldots . . . P$ P & 15 & 20 & 50 & 110 & 400 \\
\hline Fremont Wm...P & 15 & 20 & 50 & 110 & 400 \\
\hline Fendall ......P. P & 15 & 20 & - 60 & 135 & 500 \\
\hline Fairfield ......P & 15 & 20 & 60 & $\cdots$ & $\ldots$ \\
\hline First Quality ...P & 20 & 30 & 100 & . & . \\
\hline Gill $\ldots \ldots \ldots \ldots$ P & 15 & 25 & 75 & & \\
\hline Glen Mary .....P & 15 & 20 & 50 & 110 & 400 \\
\hline Gandy .......P & 15 & 20 & 50 & 110 & 400 \\
\hline Gibson & 15 & 25 & 75 & • & . \\
\hline Great Scott ....I & 1 & 20 & 50 & 110 & 400 \\
\hline Good Luck ....P & 15 & 20 & 50 & 110 & 400 \\
\hline Golden Gate ...P & 15 & 20 & 50 & 110 & 400 \\
\hline$\ldots \ldots \ldots P$ & 20 & 30 & 100 & & \\
\hline Hundred Dollar $\mathrm{P}$ & 15 & 20 & 50 & 110 & 400 \\
\hline Heritage . & 15 & 20 & 50 & 110 & 400 \\
\hline Haverland & 1 & 20 & 50 & 100 & 350 \\
\hline Highland & & 20 & 60 & $\cdots$ & $\cdots$ \\
\hline Helen Gould ....I & & 20 & 60 & & $\cdots$ \\
\hline & 1 & 20 & 50 & 110 & $408:$ \\
\hline Jim Dumas. & 1 & 20 & 50 & 110 & 400 \\
\hline Toe & & 20 & 60 & & \\
\hline
\end{tabular}

\begin{tabular}{|c|c|c|c|c|c|}
\hline & 12 & 25 & 100 & 250 & 1000 \\
\hline$\ldots \ldots \ldots$ & 15 & 20 & 50 & 110 & 400 \\
\hline Klondike $\ldots .$. & 15 & 20 & 50 & 110 & 350 \\
\hline Kellogg's Prize P & 20 & 35 & 100 & $\cdots$ & $\cdots$ \\
\hline Latest ........ I & 20 & 35 & 100 & & \\
\hline Lovett $\ldots \ldots$ P & 15 & 20 & 50 & 100 & 350 \\
\hline Marie ......... I & 15 & 20 & 50 & 100 & 350 \\
\hline Marshall .....PP & 15 & 20 & 50 & 110 & 400 \\
\hline Mathew Crawf'd P & 15 & 20 & 60 & . & . \\
\hline Minnetonka ....P & 15 & 25 & 75 & & \\
\hline Mascott $\ldots \ldots P$ P & 1 & 20 & 50 & 110 & 400 \\
\hline Meteor .......P & 15 & 20 & 60 & $\cdots$ & $\cdots$ \\
\hline Monroe $\quad . . . . P$ P & 20 & 35 & 100 & & .. \\
\hline Manhattan ....P & 15 & 20 & 60 & & \\
\hline Norwood ......P & 15 & 20 & 60 & 135 & 500 \\
\hline Nettie ........ I & 15 & 20 & 60 & $\cdots$ & $\cdots$ \\
\hline No Shore .....P & 1 & 20 & 60 & & \\
\hline Oswego $\ldots . . . P$ & 15 & 20 & 50 & 110 & 400 \\
\hline Ohio Boy $\ldots .$. P & 15 & 20 & 50 & 110 & 400 \\
\hline Oren $\ldots \ldots \ldots P$ & 1 & 20 & 60 & . & $\cdots$ \\
\hline Pearl ... & 15 & 25 & 75 & & \\
\hline Parson's Beauty $P$ & 15 & 20 & 50 & 100 & 350 \\
\hline Pennell $\ldots . . . P$ P & 1 & 20 & 50 & 100 & 350 \\
\hline Pine Apple & 15 & 20 & 60 & & \\
\hline Pride of Mich. $\mathrm{P}$ & 1 & 20 & 50 & 110 & 400 \\
\hline Paul Jones ....P. P & 1 & 20 & 50 & 110 & 400 \\
\hline Parker Earl ...P & 15 & 20 & 60 & & \\
\hline Progressive ... & 30 & 50 & 150 & 325 & 1200 \\
\hline Ridgeway $\ldots$. & & 20 & 50 & 110 & 400 \\
\hline Red Bird ......P & 15 & 20 & 50 & • & . \\
\hline Rewastico ... & 20 & 35 & 100 & & \\
\hline Springdale Bty..P & 15 & 20 & 50 & 100 & 350 \\
\hline Sample ....... I & 15 & 20 & 50 & 110 & 400 \\
\hline Steven's Late & & & & & \\
\hline Chamipon ...P & 1 & 20 & 50 & 110 & 400 \\
\hline St. Louis ..... & 1 & 20 & 50 & 9 & 325 \\
\hline Sen. Dunlap & & 20 & 50 & 80 & 300 \\
\hline Splendid & 15 & 20 & 50 & • & $\cdots$ \\
\hline Sons Prolific . & 20 & 35 & 100 & & $\cdots$ \\
\hline Superb & 30 & 50 & 150 & 300 & 1000 \\
\hline Uncle Joe & 15 & 20 & 60 & & \\
\hline Uncle Jim .. & 15 & 20 & 50 & 11 & 400 \\
\hline $3-W$ & 15 & 20 & 50 & 110 & 400 \\
\hline U. S. King Ed. & 1 & 20 & 50 & 110 & 400 \\
\hline Virginia $\ldots$. & 1 & 20 & 50 & 110 & 400 \\
\hline Warfield ... & 1 & 20 & 50 & 85 & 300 \\
\hline Wm. Belt .....P & 15 & 20 & 50 & 110 & 400 \\
\hline Wooster .......I & 15 & 20 & 60 & & - \\
\hline Warren .......P & 20 & 30 & 100 & & \\
\hline
\end{tabular}

Substitution.-We desire to furnish each customer exactly what he orders, but sometimes find the vairety all sold before his order is reached. If marked "no substitution," we are obliged to disappoint our customers by returning money late in the season, although able to supply another sort of like season and of equal if not greater value. In such case, except for new varieties for testing, unless the order is marked "no substitution," we will understand you desire us to use our best judgment for your benefit, and we will, if thus permitted, give extra count or include something new and valuable. 


\section{RASPBERRIES}

Any soil that will produce good field crops is suitable for raspberries. The red and black varieties have proven a very profitable crop for the past few years, and every fruit grower should plant a few.

We generally set Black Caps about 3 to 4 feet apart in row, and rows 6 to 7 feet apart. The red varieties may be set 6 feet by 3 feet.

\section{RED RASPBERRIES}

\section{CUTHBERT}

This is a valuable variety, well tested throughout the country. It is a rank, vigorous grower, making many plants, which should be kept cut back with the hoe or cultivator. It ripens mid-season and continues to very late. The quality is good. Dozen, $30 c ; 50,75 c ; 100, \$ 1.00 ; 1,000, \$ 8.00$.

\section{BLACK RASPBERRIES}

\section{CUMBERLAND}

One of the best, if not the very best of all the Black Caps. It is very hardy and productive. The bush is exceedingly healthy and vigorous. The fruit is very handsome and is sure to bring a good price. It is said to be the largest Black Cap known. Dozen, 35c; 50, $\$ 1.00 ; 100, \$ 2.00 ; 1,000, \$ 12.00$.

\section{GREGG}

The old standby, and has been the leading variety for years. It adapts itself to almost any condition. The canes are strong, the fruit attractive and of choice quality. It is the best late market sort. Dozen, 30c; 50, 75c; $100, \$ 1.50 ; 1,000, \$ 10.00$.

\section{PLUM FARMER}

One of the newer varieties of Black Caps. It has given great satisfaction and growers are enthusiastic over it. A vigorous grower and hardy. The fruit is large, like Cumberland, but a little earlier season. Per dozen, $35 \mathrm{c} ; 50, \$ 1.00 ; 100, \$ 2.00 ; 1,000, \$ 12.00$.

\section{BLACKBERRIES}

The culture is about the same as the raspberry. The canes should be pinched back when they reach the height of $3 \frac{1 / 2}{2}$ to 4 feet. They should be planted in rows 6 or 7 feet apart and 3 to 5 feet in the rows.

\section{SNYDER}

This is the old reliable and popular variety for cold climates. The plants are stout, rugged growers, upright in habit, and produce immense crops of fruit. It will withstand the most cold of any variety we know of. The berries are round in shape and of good flavor when ripe. Dozen, 35c; $50, \$ 1.00 ; 100, \$ 2.00$.

If wanted in larger lots, write for prices. If wanted by mail, add $10 \mathrm{c}$ per dozen postage.

\section{ELDORADO}

This is undoubtedly one of the best blackberries. Its large size and delicious quality puts it far in advance of some other varieties. It is very hardy and never winter kills in northern climate. The berries are large, jet black, borne in large clusters and ripen well together. Dozen, 35c; $50, \$ 1.00 ; 100, \$ 2.00 ; 1,000, \$ 15.00$. 


\section{AULTFATHER'S

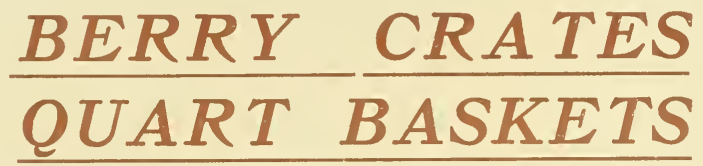

There is no package for small fruits that gives better satisfaction to the growers of small fruits, the Express Companies Commission Merchants, and Dealers generally than AultFatHER's 32-24- and 16-qt. crates with quart baskets for same.

Write for Catalog with Prices to

\section{H. H. AULTFATHER} MINERVA - OHIO

\section{PECK'S EARLY POTATOES SEED POTATOES}

Originated with Mr. Peck of Missouri and introduced by us in 1903. It is roundish oblong in form. Eyes not deep. Resembles Early Ohio for color. It is very famous in this section for the heavy yield, early ripening and good quality. We cannot say too much of the extra early variety as we feel it is one of the best. Price F. 0. B. Leslie. No. 1 size, $\$ 1.00$ per bushel; No. 2 size, $75 \mathrm{c}$ per bushel.

\section{MILLION DOLLARS}

Medium to late. Very productive. A pure white variety and resembles Carmen No. 3. We are pleased with this variety, and it certainly is worthy of trial at the low price we are offering them. No. 1 size, $\$ 1.00$ per bushel; No. 2 size, $75 \mathrm{c}$ per bushel. Half bushel at bushel rates. 

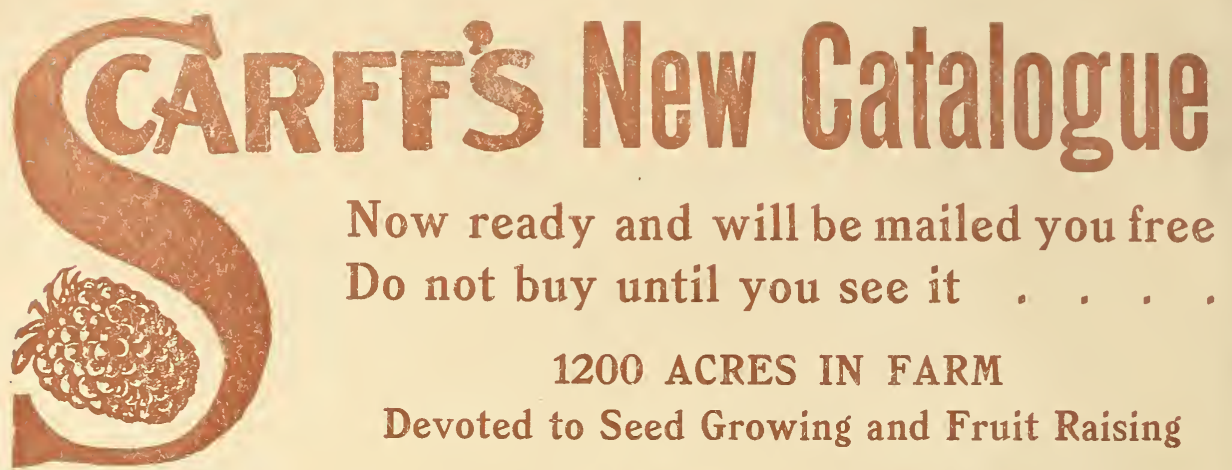

Now ready and will be mailed you free Do not buy until you see it

\section{ACRES IN FARM \\ Devoted to Seed Growing and Fruit Raising \\ See Some of the Bargains We Offer}

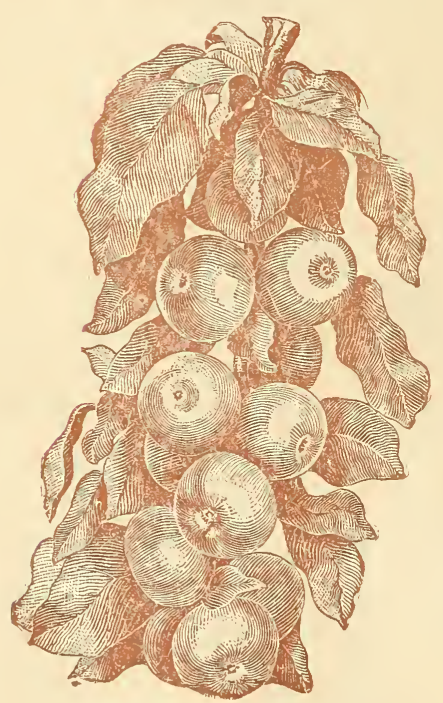

WINTER BANANA APPLE

Mayflower Peach Practically frostproof - It blooms very late and blossoms are very large, thus quite safe from damage by ordinary frost. Safe and sure for planters everywhere. This new peach originated in North Carolina, and is the earliest peach in existence; besides its color is perfectly red, which makes it one of the best and most profitable market sorts in existence. It is perfectly hardy, an abundant cropper, and should be in every home collecttion of fruit whether for the home garden or for commerical purposes. Our stock comes from the originator, and can be relied upon as being genuine and first-class in every respect.

Winter Banana Apple This valuable new apple is a to the decided Banana flavor and taste it imparts, besides it comes into bearing in two years from planting, and continues to produce ful ops each succeeding year. This fruit is large, perfect in form, golden-yellow, beautifully shaded and marbled with bright crimson. of highest quality and a good keeper- from November until rich, Tree a remarkable strong grower, of ironclad hardiness, with a large foliage that neverblights or mildews and produces enormous crops every year. A truly wonderful fruit. First-class, each, 35c; dozen $\$ 4.00$ per hundred, $\$ 30.00$. One year, by mail, each, 35c; dozen $\$ 4.00$.

McIntosh Red Hardy Canadian Apple. Medium, nearly ender, juicy. Good covered with dark red; flesh white, fine, price as Winter Banana.

Other Varieties of Apples-Winter Maiden Blush, Fall Pippin, Fameuse, Delicious, Early Harvest, Red Astrachan. Sweet Bough, Early Strawberry, Yellow Transparent, Duchess of Oldenburg, Maiden Blush, Baldwin, Ben Davis, Fallawater, Mann, Winter Rambo, Wealthy, Stark, Grimes Golden, Missouri Pippin, Wolf River, Greenville, Beauty, Arkansas Black, Gano, Jonathan, Tallman Sweet, Wagner, White Pippin, Winesap, York Imperial, Hyslop Crab, Whitney Crab, Transcendent Crab.

Price good trees, 30 cents each; $\$ 3.00$ per dozen; mailing size, 25 cents each; $\$ 2.50$ per dozen.

0ther Varieties of Peaches-Crosby, Champion, Crawfords Early, Elberta, Early Canada, Crawfords Late, Foster Globe, Mountain Rose, Old Mixon Free, Shumacher, Steadley, Stump the World, Salway, Smock Free, Carman, Alexander.

Our Best Cherries-Gov. Wood, Yellow Spanish, Dyehouse, Early Richmond, Montmorency, May Duke, English Morello.

Luscious Pears-Seckel, Duchesse, Koonce, Wilder Early, Bartlett, Clapps Favorite, Vermont Beauty, Tyson. Idaho. Kieffers Hybrid, Rossney.

Finest of Plums-Moores Arctic, Niagara, Shippers Pride, Reine Claude, Yellow Egg, German Prune, Bradshaw, Lombard, Abundance, Red June, Burbank, Harris Hardy Apricot, Nectarine.

Quinces-Orange, Champion, Meechs Prolific, Rheas Mammoth.

Send today for free Catalog giving full description of our Fruit and Seed Farms. W. N. SCARFFS, New Carlisle, Ohio 